\title{
Santos Dumont e a conquista do ar: uma nova forma de ver o mundo
}

CLAUDIA MUSA FAY*

Resumo: No início do século XX Santos Dumont realizou a conquista o ar. Entre tantas invenções nenhuma teve tanto impacto e despertou tanto a imaginação como a aviação. As máquinas voadoras foram associadas à idéia de modernidade. $\mathrm{O}$ artigo analisa algumas imagens produzidas entre (1906-1930) buscando compreender as mudanças culturais provocadas pela nova forma de ver o mundo.

Abstract: In the beginning of the 20th Century Santos Dumont conquered space. Among a number of inventions none of them has had so much impact and has triggered so much imagination as aviation. The flying machines were associated with the Idea of modernity. The article analyses some images produced between (1906-1930) with the aim of understanding the cultural changes that resulted from this new way of seeing the world.

Palavras-chave: Imagem. Arte. Aviação.

Key words: Image. Art. Aviation.

O mundo no final do século XIX estava repleto de uma tecnologia revolucionária: o motor a explosão, o telefone, o microfone, a radiotelegrafia, a lâmpada elétrica, a máquina de escrever, as fibras sintéticas e, finalmente, no início do século XX o avião. Entre tantas invenções nenhuma teve tanto impacto e despertou tanto a imaginação como a aviação. Verdadeiras multidões se reuniam para assistir às exibições aéreas e, naturalmente, pilotos e inventores tornaram-se heróis.

Quais eram as razões para tanta curiosidade e interesse? Parece que a melhor explicação é a vontade do homem de voar. Desde as mais remotas civilizações já encontramos indícios desse desejo, seja entre os egípcios, através da pintura de homens com asas, seja na mitologia grega, com Dédalo e Ícaro.

Professora do Departamento de História PUCRS.

Estudos Ibero-Americanos. PUCRS, v. XXXI, n. 2, p. 129-142, dezembro 2005 
No século $\mathrm{XX}$ houve uma revolução nos transportes e nas comunicações, anulando o tempo e a distância. A velocidade fascinou os homens, devendo ser alcançada a qualquer custo. A aviação oferecia ainda uma nova forma de olhar o mundo. A terra parecia diferente vista do céu, as cidades feias ou sem interesse se tornavam belas quando vistas de cima. A água adquiria inúmeras cores e as pessoas e animais pareciam miniaturas. Tudo isso promovia um espetáculo para os olhos e dava a sensação de ser possível deixar os pequenos problemas na terra e ficar próximo das verdades eternas.

Um novo mundo aberto foi aos homens é repleto de sensações. Paris virara a capital mundial da aviação desde a fundação do Aéro-club de França em 1898. Depois da difusão dos grandes balões, em 1880, e dos dirigíveis inflados a gás, em 1890 - os chamados "mais leves que o ar" - chegara à hora dos aparelhos voadores práticos, menores e controláveis - "os mais pesados que o ar". Sonhados por muito tempo agora eram possíveis graças aos avanços tecnológicos: a aerodinâmica, a engenharia de estruturas, do desenho dos motores, da química dos combustíveis combinada as novas tecnologias permitiam projetar as máquinas tão desejadas. Um exemplo interessante, das sensações de um vôo foi relatado por Santos Dumont no seu primeiro vôo num balão.

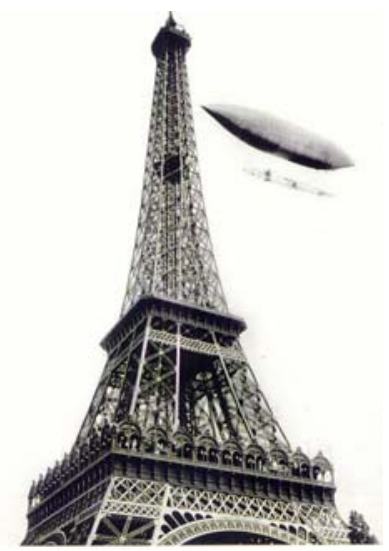

Museu Paulista. Santos Dumont, n⿳ํㅡㄹ, julho de 1901.

Fiquei estupefato diante do panorama de Paris visto de grande altura; nos arredores, campos cobertos de neve... Era inverno.

Durante toda a viagem acompanhei as manobras do piloto; compreendia perfeitamente a razão de tudo quanto ele fazia. Pareceu-me que nasci mesmo para a aeronáutica. Tudo se me apresentava muito 
fácil; não senti vertigem, nem medo. E tinha subido... (SantosDumont, 2000, p. 26).

Santos-Dumont (1883-1932) tornou-se uma referência em Paris no início do século e passou a ser muito conhecido através do mundo. ${ }^{1}$ Em 1901, contornou a Torre Eiffel com um Dirigível e recebeu o prêmio Deutsch de 100000 francos (\$20 000 dólares) passou a ser fotografado e assediado em todos os momentos. Charmoso, sua roupa, seu chapéu seu relógio, passou a ser moda, como descreve um contemporâneo:

[...] A multidão anoitecia e amanhecia-lhe à porta, para vê-lo apenas um instante, entrar ou sair, entre aclamações ensurdecedoras. Por vezes interrompiam-lhe o sono, altas horas; queriam vê-lo, palpá-lo, ouvi-lo e era forçoso aquiescer, levantar-se, abrir as janelas, sofrer a glória... Os espetáculos interrompiam-se à sua chegada; as orquestras estacavam, congestionava-se o transito à sua passagem. Foi caricaturado, biografado, pintado, esculpido, endeusado, anedotizado, criado por todas as penas, todos os lápis, todos os buris... E para completar o documentário humano de seu triunfo absoluto foi ridicularizado e negado por muitos, até por sócios do Aero-clube de França, tímidos competidores, gênios incompreendidos aeronautas de salão... (Karson, 1963, p. 110)

Mas logo vieram outros heróis como: Blériot, Voisin, Farman, Delagrange, Curtiss, Fokker e muitos outros precursores. Em pouco tempo foram se tornando prósperos industriais.

Deve-se ressaltar o avanço técnico na fotografia que simultaneamente ao progresso das máquinas voadoras com a invenção dos filmes flexíveis em 1889. Facilitaram a produção de câmaras modernas, mais sensíveis a luz, mas velozes e fáceis de manejar. Em conseqüência aumentaram os fotógrafos e que registraram os primeiros passos da aviação. A imagem dos primeiros pilotos estampadas nos jornais popularizou o avião e estimulou a vocação de muitos jovens. Ocorreu uma glamourização da ousadia de voar. Homens de muita coragem dispostos a arriscar suas vidas e suas finanças. Entre os pioneiros inventores da aviação existiam industriais, homens de negócios, herdeiros de famílias endinheiradas ao lado de homens com pouca formação teórica e uma multidão de

1 Entre 1898 e 1902 Santos-Dumont manteve contrato com algumas agências de notícias. Pelo menos quatro agências realizavam o trabalho: Le Courrier de la Presse, Argus de la Presse, Press Cuttings Buurreau e Manhattan Press. Em 1899, pelo menos 133 notícias foram publicadas sobre ele. Em 1900, o número cresceu para cerca de 200. Mas em 1901 já ultrapassava 7 500, para cair, em 1902, para cerca de quatro mil e baixar para pouco mais de 600, em 1903. BARROS, Henrique Lins. Santos Dumont a invenção do vôo. Rio de Janeiro : Zaahar, 2003, p. 148. 
aspirantes ao vôo. Inventar aviões exigia antes de tudo coragem e muitos recursos financeiros. Construir um aparelho significava contratar mecânicos, oficinas, hangares e arriscar a própria vida. Voar era uma glória para homens extraordinários. Mas para os pioneiros da aviação existiam inúmeros riscos os desafios. Entre 1909 e 1912 Ferber, Rolls, Delagrange e Latham perderam a vida entre tantos outros.
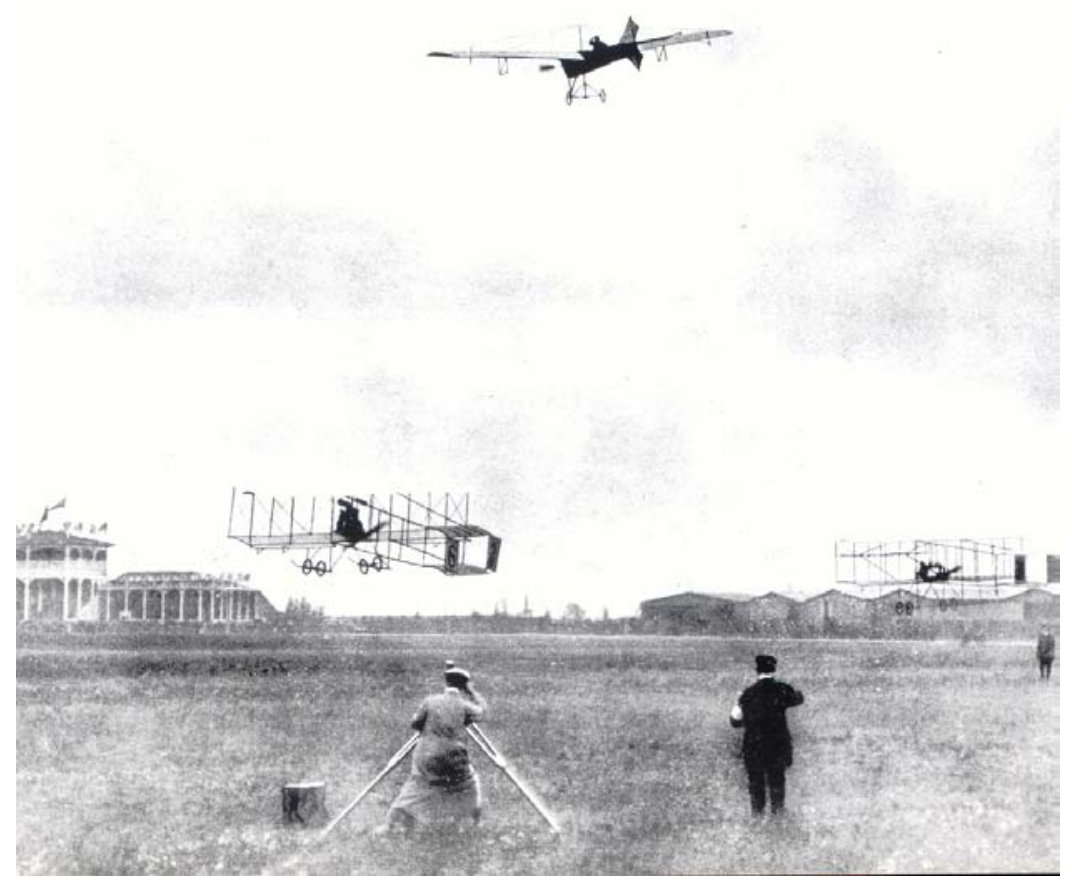

Latham, Paulhan and Farman fotografados em Reims durante a Semana de Aeronáutica em agosto de 1909.

Logo a imagem de liberdade, do risco, da velocidade e da superação passou a ser representada de muitas formas através de artigos em jornais, ilustração em capas de revistas, fotografias, cartões postais, poemas, histórias em quadrinhos, cartazes, desenhos e pinturas.

Dessa forma a imprensa, o cinema e a publicidade passaram a se apropriar da idéia de modernidade que o avião trazia. $\mathrm{O}$ cinema surgiu com uma natural afinidade, transmitindo de forma realista o movimento ao utilizar as imagens aéreas tinha o poder de delei- 
tar e paralisar as platéias, especialmente se as cenas envolvessem o perigo.

A publicidade criou anúncios utilizando as máquinas voadoras para vender variados produtos. Um exemplo desta utilização foi à realização do grande meeting de Reims ${ }^{2}$ que marcou, pode-se dizer, a entrada do aeroplano na era comercial .

Entre 22 e 29 de agosto de 1909, a cidade de Reims situada a cento e cinqüenta quilômetros de Paris, reuniu meio milhão de pessoas para assistir as provas de aviação. A grande semana foi financiada pela prefeitura da cidade e pelos fabricantes de vinhos finos e Champagne da região. O sucesso foi enorme reuniu competidores da França, Inglaterra e até um dos Estados Unidos. As autoridades que compareceram nas tribunas de honra foram aclamadas ao mesmo tempo que os heróis do dia, entre elas o presidente da república francesa Armand Falliéres, a esposa de Teddy Roosevelt, presidente dos Estados Unidos, o político britânico, David Lloyd George e o magnata da imprensa Lord Northcliffe proprietário dos jornais The Times e Daily Mail Neste festival os organizadores arrecadaram 80000 dólares e a maior parte das marcas de Champagne famosas como, Heidsieck e Veuve Clicquot associaram sua imagem a festa de luxo. A imprensa internacional realizou uma grande cobertura e ofereceu prêmios aos vencedores.

As exibições eram a forma de comunicar às grandes massas os avanços técnicos da aviação. Os pilotos e as máquinas apesar de pouco numerosos, ganharam o mundo através das representações.

A aviação começou a se afirmar como um esporte que levava o público ao delírio. Nesses primeiros tempos poucos voavam de fato e a maioria apenas sonhava. Muitos nem imaginavam a possibilidade que um dia fossem viajar de avião, deixando o conforto, a segurança, a regularidade e a relativa rapidez dos trens para viagens próximas e dos navios transoceânicos para viagens mais longas. O avião era frágil, instável, até mesmo perigoso e, por isso, estava reservado aos corajosos, e não ao prudente viajante. Dessa maneira a maior parte das pessoas tomou contato com avião através de símbolos criados para que fossem incorporados ao dia-a-dia das pessoas comuns, dando-lhes uma aparência moderna e cosmopolita através da jaqueta de couro, da écharpe, dos óculos, do relógio de pulso e do chapéu de abas baixas.

2 Meeting de aviação significava uma reunião de pilotos e aviões para demonstração. Eram realizadas provas de velocidade, distância e resistência. Além disso, era oferecido ao publico refeições e bebida. 
Essa nova forma de ver o mundo, trouxe a sensação de aventura, a confiança na máquina possibilitou a conquista do desconhecido e a simpatia das massas.

Os parisienses acompanhavam fascinados as audácias dos aviadores. Cada proeza era narrada em detalhe. Uma elite extravagante de jovens cultos elegantes e ricos passou a representar estas vivências.

Paris foi cenário de progresso e inovações que ocorreram também no campo das artes plásticas. Di Cavalcanti, escreveu em 1933 procurando explicar como os artistas enxergavam o mundo no inicio do século.

[...] criou-se o que se chama "dinamismo moderno". Esse dinamismo que fez construir arranha-céus de 60 andares, que fez voar esquadrilhas de aeroplanos em volta do mundo, que nós transmite noticias pelo rádio, do lugar mais longínquo, que atravessa a estratosfera....

[...] Esse dinamismo, apregoado e louvado, vê-se de um momento para o outro na iminência de se destruir porque todos os que o criaram se esqueceram que o pivot de todo esse o movimento é o homem, e o homem ainda é escravo de uma civilização inimiga da ciência, porque ainda vive presa aos prejuízos de uma tradição espiritual deformada, em benefícios de interesses, os mais subalternos. ${ }^{3}$ (Amaral, 2003, p. 444).

A pintora brasileira Tarsila do Amaral, recém chegada ao Brasil em 1923. respondeu ao Jornal Correio da Manhã ${ }^{4}$ sobre o "estado atual das artes na Europa". Tarsila fez um balanço entusiasmado da arte, e explicou:

$\mathrm{O}$ século XX procura nas artes a expressão que corresponde às descobertas cientificas e ao tumulto das cidades modernas (Amaral, 2003, p. 417).

Indagada sobre os artistas da época; respondeu que,

a Europa vivia uma espécie de "renascimento" e particularmente na França, onde em 1908, manifestou-se uma forte reação, sempre crescente a decadência imitativa das artes plásticas. Chamou-se esta reação cubismo, como, entre nós, se chama futurismo a tudo que reage contra fórmulas passadas. Corresponde ao expressionismo do norte da Europa e o futurismo na Itália (Amaral, 2003, p. 417).

3 DI CAVALCANTI, A exposição de Tarsila do Amaral, a nossa época e a arte. Diário Carioca, Rio de Janeiro, 15 out. 1933. Citado em AMARAL, Aracy. Tarsila sua obra e seu tempo. São Paulo: Edusp, 2003, p. 443.

4 Tarsila do Amaral entrevista ao jornal Correio da Manhã, em 25 dez. 1923. Citado em AMARAL, op. cit., p. 417. 
Segundo declarou a artista "a coisa andava no ar" foi o caminho iniciado por Cézanne e seguido por Picasso , Braque, Albert Gleizes, Fernand Léger e outros.

Tarsila foi morar na França, a partir de 1920, estimulada pelo pianista e compositor Souza Lima, amigo de sua família, que estudava na Europa. Segundo seu relato, era linda e aventureira, chegou mesmo a experimentar a novidade da época; o avião. Foi com esse amigo que a artista realizou em Paris seu "batismo no ar".

[...] Por 60 francos dava-se uma volta de avião por Paris e redondezas. Tarsila deu a idéia e fomos, era uma novidade,uma verdadeira aventura: davam-nos um abrigo de peles, grandes óculos (só iam duas pessoas além do piloto, e os lugares eram descobertos) embarcamos para aquele passeio rápido num avião frágil, que parecia de papel. Depois de sobrevoar a capital, a uns 200 metros de altitude, descia-se que alívio! á terra (Amaral, 2003, p. 54).

No início, a artista estudou na Académie Julien. Depois passou para a academia de Emile Renard. Em maio de 1923 conheceu o poeta Blaise Cendrars que foi o responsável por introduzir Tarsila e Oswald ao mundo artístico e literário francês, onde teve contato com Lhote, Léger e Gleizes. Nesta ocasião o poeta presenteou Tarsila com uma imagem da Torre Eiffel pintada por ele em 1913 depois de um período de intima convivência com o casal Sonia e Robert Delaunay (Amaral, 2003, p. 103).

Segundo Blaise Cendrars ele e Robert Delaunay nos anos 1910 e 1911;

[...] éramos talvez os únicos em Paris, Robert Delaunay e eu, a falar de máquinas e de arte e a ter vagamente consciência da grande transformação do mundo moderno (Eulálio, 2001, p. 143).

Conta que naquela época trabalhava em Chartres com Borel, na montagem de seu avião e Robert havia trabalhado algum tempo como mecânico em uma serralheria de arte. Um dia voltando de Chartres, o poeta caiu do automóvel e quebrou a perna. Ficou recuperando-se no Hôtel du Palais durante 28 dias, da janela do seu quarto enxergava a torre Eiffel.

[...] Assim, todas as manhãs quando o garçon trazia o café da manhã, empurrava as venezianas e abria por inteiro a janela, eu tinha a impressão que ele me trazia Paris na sua bandeja. Eu via pela janela a torre Eiffel como uma garrafa de água cristalina, as cúpulas dos Invalides e do Panthéon como uma chaleira e um açucareiro, e o Sa- 
cré-coeur branco e rosa, como um bombom. Delaunay vinha me fazer companhia todos os dias... (Eulalio, 2001, p. 143). ${ }^{5}$

O pintor francês Robert Delaunay (1885-1941) A partir de 1908, começou a inovar, suas obras associavam o avanço da aviação aos símbolos de modernidade.

Seus primeiros estudos sobre a Torre Eiffel foram feitos a partir de uma fotografia, um cartão postal que a artista russa, Sonia Terk, que viria a ser sua esposa, presenteou-lhe. Era a foto de um avião contornando a Torre Eiffel em 1909.

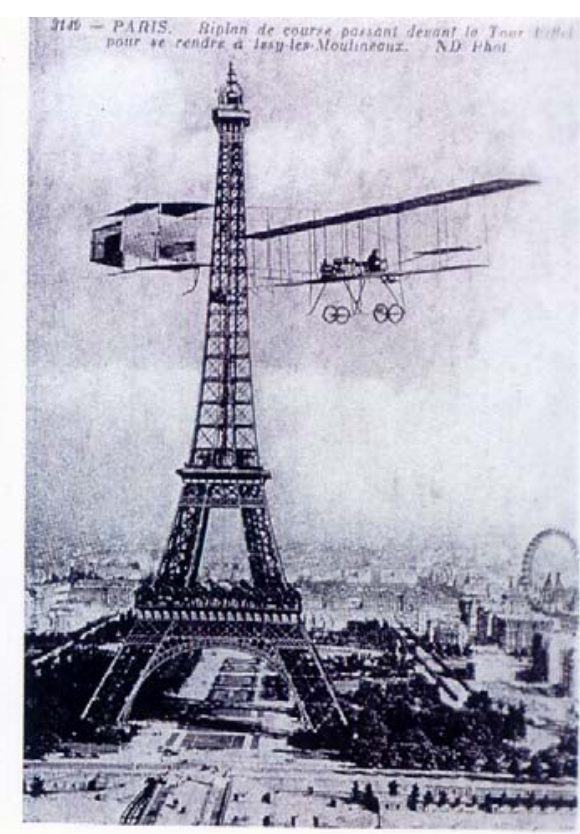

Cartão postal de Paris Biplano e Torre Eiffel.

A Torre Eiffel, pela sua modernidade fascinou Delaunay e ele vai pintá-la muitas vezes. Construída para Exposição Mundial de 1889 foi o maior edifício erguido pelo homem até então.

No entanto não tinha uma função especifica, até 1906 quando recebeu uma estação e passou a emitir sinais de rádio. Desenhada pelo engenheiro francês Gustave Eiffel, a torre possibilitou que os parisienses pudessem ver sua cidade do alto. Criado um novo e excitante ponto de vista.

5 Tendências Gerais da Estética Contemporânea - Conferência feita por Blaise Cendrars em 1 e 12 de junho de 1924, à sala São Paulo exposição de quadros de , Léger, Delaunay, Gleize, Severini, Segall e Tarsila do Amaral . Citado em: EULALIO, Alexandre. A aventura brasileira de Blaise Cendrars. São Paulo: Edusp, 2001, p. 143. 
Apesar do êxito da obra de engenharia, muitos foram contra sua construção questionaram sua estética, a ausência de uma função e desejavam que fosse destruída ao término da exposição. Quando a torre ficou pronta foi aceita pela população e se tornou um símbolo da cidade de Paris. Muitos artistas como Dufy, Chagall, Utrillo, Léger e Rousseau a representaram em suas obras.

Tarsila do Amaral, no início dos anos $20^{6}$ adquiriu entre as diversas obras, entre elas uma pintura de Delaunay da serie Tour Eiffel pintada em 1911.7 Segundo relatou a artista:

Entre os quadros de minha coleção de pintores modernos, a Torre Eiffel de Robert Delaunay, é o mais discutido, o que mais aviva a curiosidade, o que mais provoca entre os leigos discussões e cara feia [...] o quadro se impõe pelas grandes dimensões, pela execução dentro dos moldes cubistas, pela agressividade da composição. [...] Perguntas e suposições se sucedem: Será que o artista viu mesmo a Torre Eiffel deste jeito? Isto deve ser um terremoto. [...] Tudo está despencando. [...] Quem sabe se ele pintou olhando da base? Nada disso. Delaunay integrou-se ao movimento cubista e sentiu, como seus colegas, a febre do dinamismo, o delírio do desenho hieroglífico criado pela recente corrente estética, a ânsia de concretizar o novo estado de espírito em ebulição. A Torre Eiffel é um símbolo: está para Paris como o Pão de Açúcar para o Rio de Janeiro ou como a ponte dos suspiros para Veneza." (Amaral, 2004, p. 34)

Quando retornou ao Brasil a casa de Tarsila era para os modernistas de São Paulo uma iniciação principalmente para aqueles que não podiam viajar regularmente para Europa como relatou Renato de Almeida no inicio de 1924:

[...] não foi sem uma viva sensação de curiosidade que entrei no atelier da Sra Tarsila do Amaral. Ia ter o primeiro contato com o cubismo, que só conhecia através de livros e infiéis reproduções fotográficas $[\ldots]$

Esse contato não era fácil "Aquela Torre Eiffel de Delaunay num tumulto de imagens e massas que se deslocam, balançam e se precipitam... as formas e cores dissociadas e díspares de Gleizes, as figuras deformadas de Léger... (Amaral, 2003, p. 144).

6 A pesquisa realizada pela autora e Fernanda Carvalho demonstrou o extraordinário nível de vida da artista. Incluindo além de toaletes de Jean Patou e Paul Poiret, obras de arte e artigos de decoração em AMARAL, Aracy. op. cit., p. 10.

7 A obra também conhecida por Champs de Mars: La Tour Rouge, encontra-se hoje no Art Institute de Chicago, e foi adquirida na Galeria de Léonce Rosemberg pela quantia de 1,5 mil francos. AMARAL, Aracy. op. cit., p. 11. 


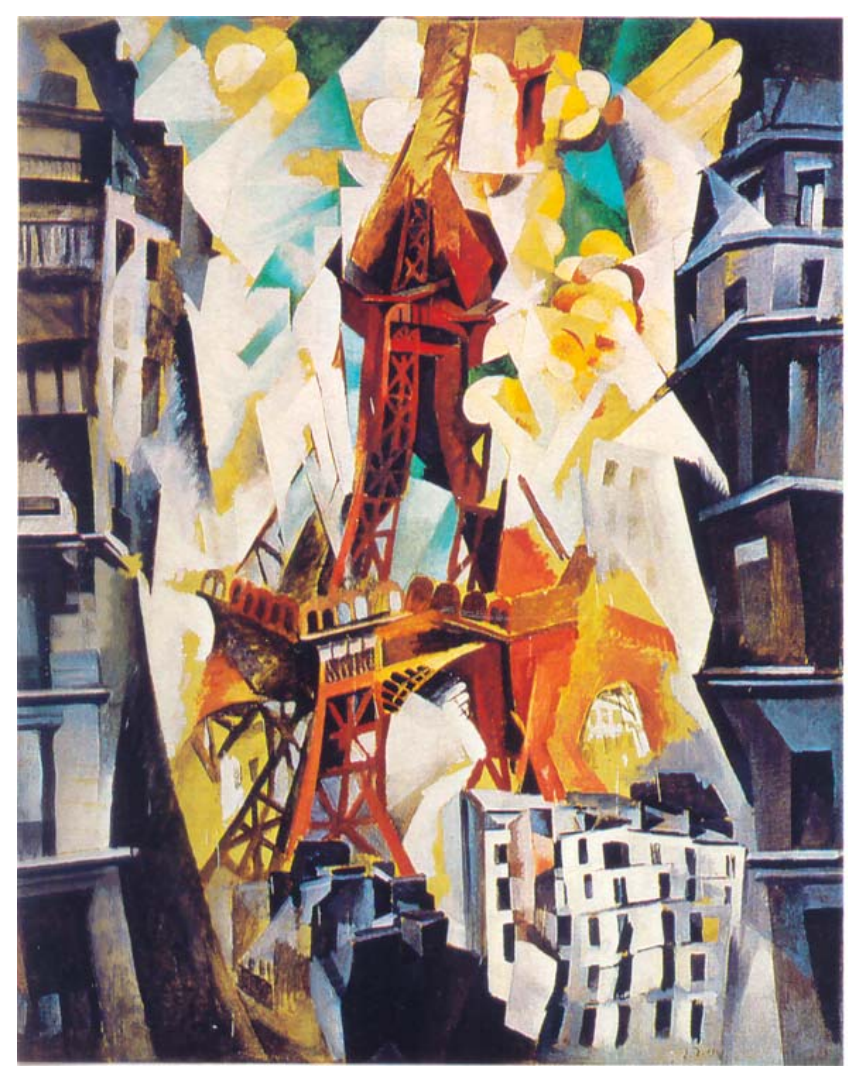

Robert Delaunay.

Campo de Marte. A torre vermelha (Champs de Mars. La Tour Rouge), 1911. Óleo sobre tela, $160,7 \times 128,6 \mathrm{~cm}$.

Chicago, Art Institute.

O entusiasmo do público com o progresso da aviação e os prêmios oferecidos pela imprensa da época proporcionou novas e crescentes emoções. Em 1909 O jornal Daily Mail lançou um novo desafio; a travessia do canal da Mancha. Uma loucura para época voar sobre o mar. Blériot conseguiu atravessar o canal e Guilherme II, imperador da Alemanha, resumiu seu feito numa única frase: "A Inglaterra não é mais uma ilha" (Barros, 2003, p. 92). profetizou:

Santos Dumont, seguindo de perto as realizações do amigo 
Essa transformação da geografia é uma vitória da navegação aérea sobre a navegação marítima . Um dia, talvez, graças a você, o avião irá atravessar o Atlântico (Barros, 2003, p. 92).

Em 1913, Delaunay pintou o quadro "Sol, Torre e Avião", o artista representou nesta obra três imagens ressaltando a tecnologia duas estavam no título e a terceira visível apenas para os observadores atentos. Era a de uma roda-gigante.

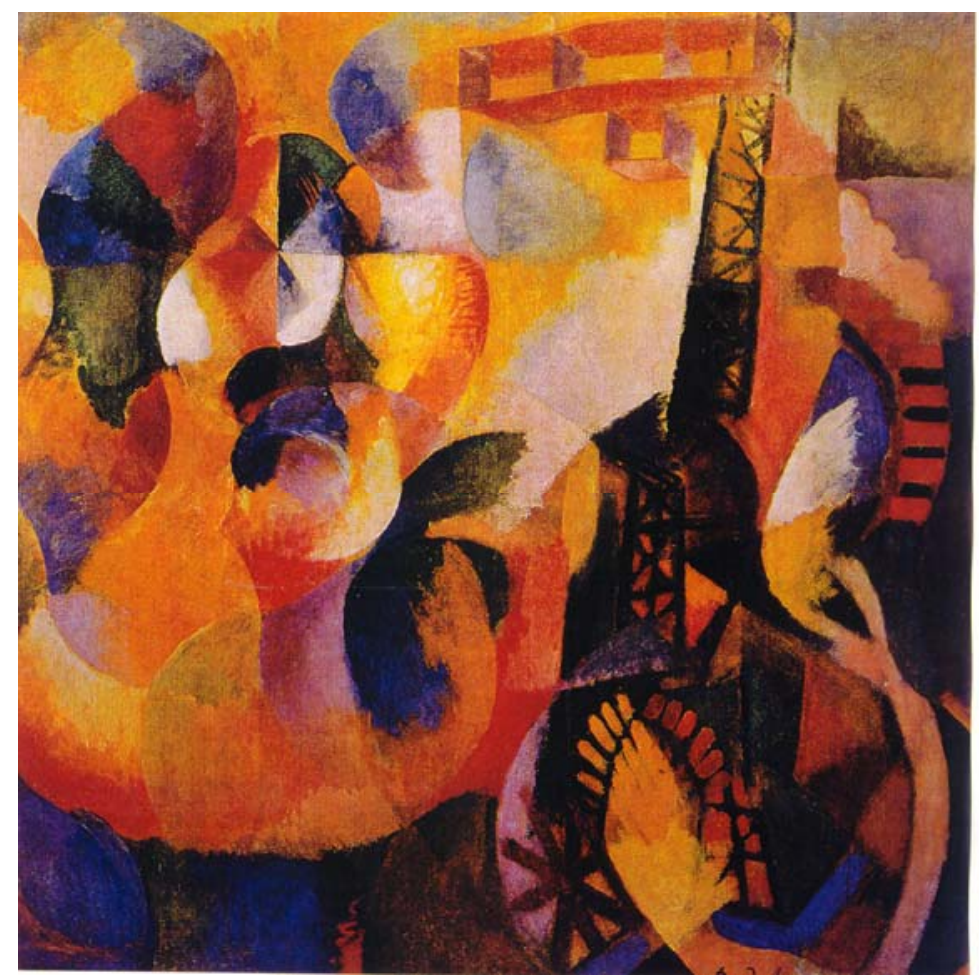

Robert Delaunay.

Sol, Torre, Aeroplano (Soleil, Tour Aéroplane), 1913.

Óleo sobre tela, 132,0 X 129,0 cm.

A. Conger Goodyear Fund, 1964.

Albright-knox Art Gallery

Nessa obra Delaunay revelou o novo e celebrou a modernidade e a máquina. $\mathrm{O}$ artista utilizou na obra símbolos de grande excitação na época como radio, avião, velocidade. 
No alto da imagem aparece o avião biplano de Voisin e ao lado uma roda-gigante. Ela aparece no meio a direita da tela, e lembra escada ou mesmo uma roda-d'água.

Delaunay demonstrou na pintura seu entusiasmo pela nova tecnologia de seu tempo. Para Delaunay a tecnologia não era contaria a natureza, ele acreditou que ambas podiam conviver harmoniosamente. $\mathrm{O}$ sol mencionado no titulo da obra esta em tudo, com calor das cores transmitindo energia. $\mathrm{O}$ sentimento do artista se reflete nos discos coloridos representam os ritmos do universo a consciência do moderno. A torre marco da engenharia francesa e a roda-gigante um artefato norte-americano.

Tarsila do Amaral vivenciou estas experiências, sua casa era freqüentada pelos artistas modernos, sua vida social intensa bem com sua formação foram marcadas profundamente por esta fase vivida em Paris. Como relatou o amigo Souza Lima:

"Foi nesta época a grande homenagem prestada a santos Dumont pelo embaixador brasileiro Souza Dantas, de 500 talheres. Neste jantar, marcado para 8:30 e para o qual eu estava de casaca , Tarsila atrasou-se , chegando mais de 9:15. Ela vinha com um manteau vermelho de gola alta..." é o manteau modelo Jean Patou, com que Tarsila se auto-retratou na tela Manteau Rouge, de 1923, hoje na coleção do Museu Nacional de Belas Artes, do Rio de Janeiro.

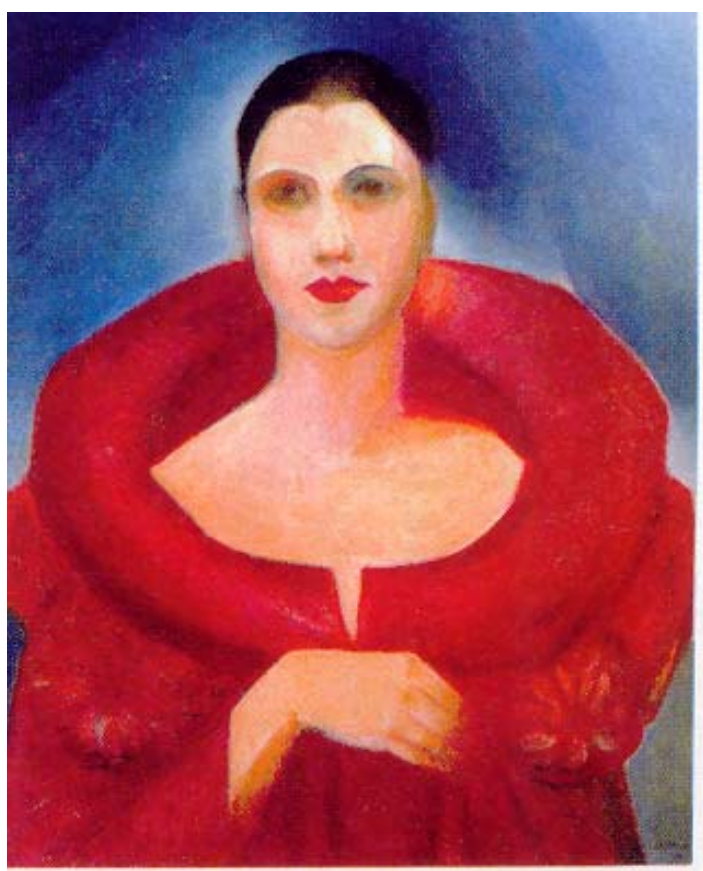

Tarsila do Amaral. Auto-retrato 1923 óleo sobre tela $73 \times 60 \mathrm{~cm}$.

Coleção Museu Nacional. 
Segundo suas palavras Tarsila resumiu "[...] a verdadeira Paris, que me deixou impressões indeléveis foi a Paris de 1923" (Amaral, 2003, p. 95).

Em 1924 o poeta Cendrars aceitou o convite de Tarsila e Oswald para conhecer o Brasil. O casal resolveu iniciar a visita pelo Rio de Janeiro na véspera do carnaval. A festa popular contagiou e entusiasmou o grupo. Tarsila desenhou os embriões de Morro da favela e carnaval em Madureira tela em que pintou a torre no meio da favela. O quadro revela uma contradição entre o progresso cientifico e as condições de atraso e pobreza da favela. Mostra um Brasil, de Santos Dumont, capaz de circunavegar a torre Eiffel civilizado e moderno convivendo com a miséria e o atraso da favela.

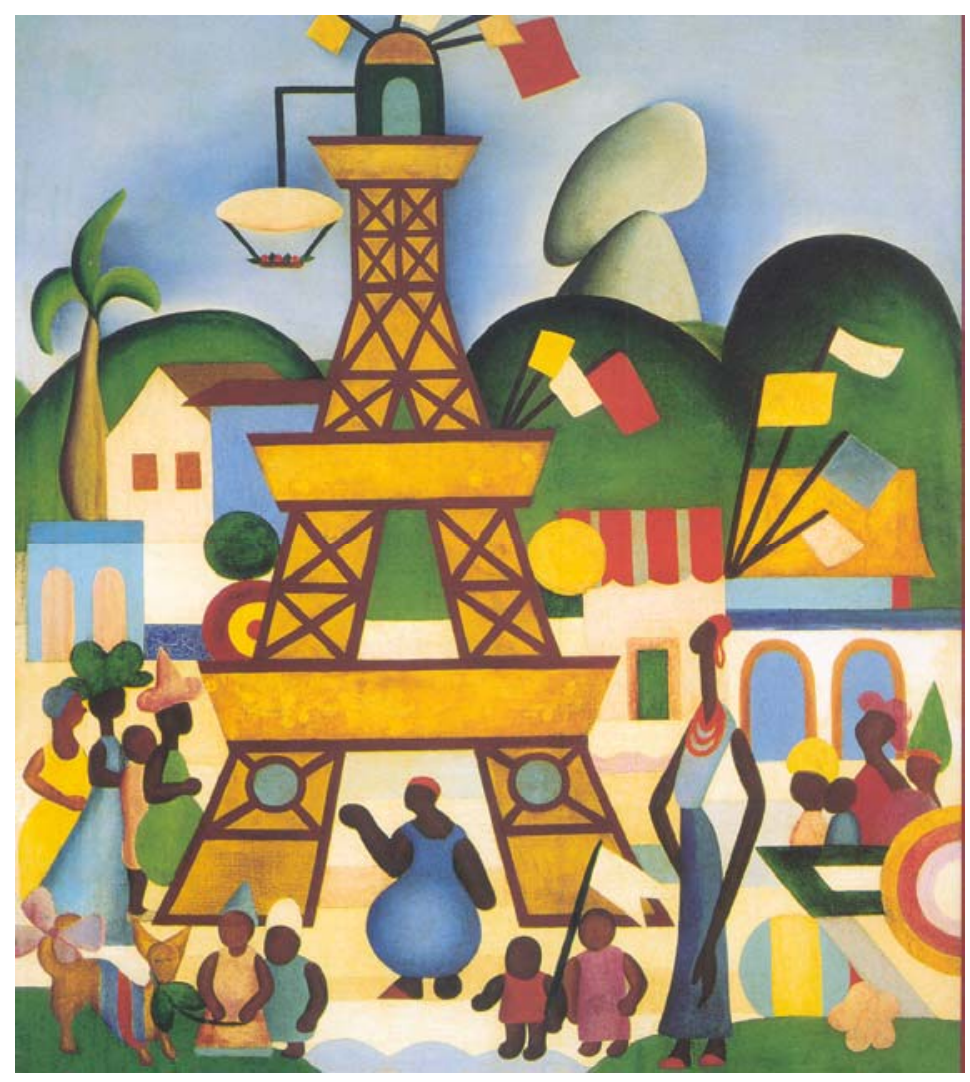

Tarsila do Amaral.

Carnaval em Madureira, 1924, óleo sobre tela 76 × $63 \mathrm{~cm}$. Coleção particular São Paulo. 
Nesta fase, conhecida como Pau Brasil apesar dos problemas urbanos da cidade Tarsila valorizou o nacional através das curvas e das cores. Ressaltou o feito do brasileiro Santos Dumont, pois é, o seu dirigível e não o biplano de Voisin que está ao lado da torre Eiffel.

Tudo isso, para demonstrar que a aviação tem implicações simbólicas, além das implicações técnicas. Todos esses sonhos, símbolos e mitos, construídos ao longo dos anos deixaram muitas marcas que podemos perceber até os nossos dias.

Há 100 anos a humanidade realizou o antigo sonho de voar. Neste curto espaço de tempo em termos históricos, o desenvolvimento técnico foi imenso. Sabemos que as mudanças culturais são mais lentas e isso nos faz refletir sobre a presença da aviação em nosso cotidiano, mesmo para aqueles que ainda hoje não tiveram a oportunidade de voar.

\section{Referências}

AMARAL, Aracy. Tarsila sua obra e seu tempo. São Paulo: Edusp, 2003.

AMARAL, Tarsila. Tarsila por Tarsila. São Paulo: Celebris, 2004.

BARROS, Henrique Lins. Santos Dumont a invenção do vôo. Rio de Janeiro: Zahar, 2003.

SANTOS-DUMONT, Alberto. O que eu vi, o que nós veremos. São Paulo: Hedra, 2000.

EULALIO, Alexandre. A aventura brasileira de Blaise Cendrars. São Paulo: Edusp, 2001.

FAY, Claudia Musa. Crise nas Alturas: a questão da aviação civil (1927-1941). Tese, UFRGS, 2001.

KARSON, Paul. A conquista dos ares. Porto Alegre: Globo, 1963.

WOHL, Robert. A passion for wings: aviation and the western imagination 1908-1918. Yale University Press, 1994. 